\title{
Analysis of Audit Opinion of Financial Statements From State Institutions: Indonesia Empirical Study, Period 2012-2017
}

\author{
Fransisca Listyaningsih Utami ${ }^{1}$, Yananto Mihadi Putra ${ }^{1}$, Putri Renalita Sutra Tanjung ${ }^{1}$ \& Lucky Nugroho ${ }^{1}$ \\ ${ }^{1}$ Faculty of Economics and Business, Universitas Mercu Buana, Jakarta, Indonesia \\ Correspondence: Lucky Nugroho, Faculty of Economics and Business, Universitas Mercu Buana, Jl Meruya Selatan \\ No.1, Jakarta Barat, Jakarta, Indonesia.
}

Received: March 31, 2020

doi:10.5430/ijfr.v11n5p150
Accepted: June 9, 2020

Online Published: September 21, 2020

URL: https://doi.org/10.5430/ijfr.v11n5p150

\begin{abstract}
This study aims to compare the results of BPK's opinion on the financial statements of state institutions against the quality of implementation of state institutions during 2012-2017. The results showed that the quality of LKKL presentation had improved throughout the 2012-2017 period. Improving the quality of financial reporting of state institutions can be seen from the increasing number of entities that obtain Unqualified Opinion and the tendency to reduce the number of the institution that obtain Qualified Opinion and Disclaimer opinions. Improving the quality of financial reporting shows that local government entities have been able to present their financial reports correctly and in accordance with applicable principles. In addition, good financial reporting can also be an indication that the entity has a good performance in accordance with the target that has been committed.
\end{abstract}

Keywords: audit opinion, audit finding, corruption cases

\section{Introduction}

The fraud committed by the auditor of the Supreme Audit Board (BPK) was revealed by the Corruption Eradication Commission (KPK) with the arrest of a number of 23 BPK auditors from 2005 to 2017. The arrest was due to BPK auditors conducting transactions with unqualified audit opinions (WTP) at institutions the government being audited (Hendri, 2017). That is because the WTP is the highest opinion of the BPK on financial statements that meet government accounting standards. The achievement of WTP opinion for government institutions is a matter of pride and accomplishment. Also, by obtaining WTP, it can extend the leadership period of the government institution (Effendy, 2013; Wahab et al., 2013; Wungow., 2016).

Also, motivation to get WTP is a good thing. Thus, there are efforts to improve the presentation of financial statements based on generally accepted accounting principles (GAAP), implementing good governance and professionalism in carrying out their duties. Meanwhile, the motivation to obtain WTP opinion with illegal and not commendable mechanisms such as bribery is an act of criminality because it affects the financial losses of the state. However, there is an opportunity for collusion between government agencies and BPK auditors to obtain WTP opinions by paying the person. These acts of corruption are of concern to the KPK and the police to be eradicated. The role of the BPK in preventing corruption has an important role where there are many corruption cases committed by state officials so that it has an impact on state financial losses (Putra, 2018). The information about the perpetrators of corruption from state officials in the 2011-2017 period a total of 418 persons are in table 1.

Indicators of the quality of financial statements of the government institutions are shown by the opinion of the government's external auditor (BPK) on the presentation of government financial statements. The BPK auditor's opinion is based on the results of the examination of the financial statements of government institutions consisting of: (i) Central government financial reports (LKPP); (ii) Ministry/agency financial report (LKKL); (iii) Local government financial reports (LKPD). Also, BPK opinion types consist of: (i) Adverse opinion (TW); (ii) Disclainer Opinion (TMP); (iii) qualified opinion (WDP); (iv) Unqualified opinion (WTP). Based on the type of BPK's opinion, which is an opinion that shows that the government institution has presented its report properly is the opinion of the WTP (Putra, 2018). 
Table 1. List state officials corruption in period 2011-2017

\begin{tabular}{lr}
\hline Position in Government & Amount \\
\hline Government Officials (Echelon) & 155 \\
\hline Central and Regional People's & 134 \\
\hline Representatives (DPR and DPRD) & 60 \\
\hline Regional Head (Walikota/Bupati) and & 25 \\
\hline Deputy & 18 \\
\hline Ministers and Heads of State Institutions & 15 \\
\hline Jovernor & 7 \\
\hline Commissioner of State Agencies & 4 \\
\hline Ambassador & $\mathbf{4 1 8}$ \\
\hline Total &
\end{tabular}

Source: (Widyanita, 2017)

The operational budget of government institutions is sourced from taxes received by the government. Therefore the use of the budget must be accounted for and transparent (Purba, Sarpingah, \& Nugroho, 2020). One of them is through auditing the financial statements of these government institutions by the BPK audit. The preparation of government financial statements based on government accounting standards (SAP). The better the results of auditing financial statements from government agencies by getting WTP opinion from BPK, the more people will trust the government related to using tax money following existing regulations and not be corrupted by state officials. Also, the WTP opinion is one indicator that the government institution has good governance so that it helps stakeholders in making strategic public policies and the going concern of the institution (Ballesta \& García-Meca, 2005; Nugroho et al., 2018; Suryo et al., 2019).

Government Accounting Standards (SAP) are accounting principles applied in preparing and presenting government financial statements that consisting of LKPP and LKPD. Furthermore, SAP aims to realize transparency and accountability in the administration of government accounting, as well as to improve the quality of LKPP and LKPD based on Government Regulation of the Republic of Indonesia No. 71 of 2010 (Nugroho \& Kiranti, 2017; Sondakh \& Mentu, 2016). Therefore, SAP is one of the crucial aspects needed to improve the quality of governance of state financial institutions and government financial reporting (Cohen et al., 2004). Also, SAP itself needs to be developed to improve financial accounting practices in the environment of government organizations and follow the dynamics of financial statement disclosure (Biondi, 2012).

The motivation of this research is to find out the extent of the performance of government institutions that have the ability to achieve their commitments and perform well. Therefore, to find out the achievement, it can be seen from the progress of achieving audit opinion, the more government institutions that get an unqualified opinion, it can be assumed that more government institutions have good performance. This study aims to analyze the impact of giving an opinion on the BPK's audit results on the financial statements of state institutions on the quality of the implementation of state institutions. As for the scope of the quality of the organization of state institutions in this study is limited to the suitability of the application of the State Ministry based on the ten principles of organizing public institutions contained in Decree of the State Minister Number 63/KEP/M.PAN/7/2003 concerning General Guidelines for Public Services.

\section{Literature Review}

A state institution is a body or organization that carries out functions and implements law within the framework of the state and government structure and system. Therefore, state institutions are bodies formed based on the constitution or laws and regulations that apply to a country (Grilli et al., 1991). Whereas in Indonesia, the state ministry, according to the 1945 constitution, is part of a state institution in charge of specific affairs in government to assist the president in organizing a state government where the formation, amendment, and dissolution of his ministry is regulated in the law. In carrying out its duties as stipulated in Article 8 of Law Number 39 the Year 2008 concerning State Ministries, the State Ministry carries out the functions of the formulation, stipulation, and implementation of policies in its fields, management of state property/assets that are its responsibility, supervision of the implementation of tasks in their areas and implementation technical activities from the center to the regions. Whereas in Indonesia, the state ministry, 
according to the 1945 constitution, is part of a state institution in charge of specific affairs of government to assist the president in organizing a state government where the law regulates the formation, amendment, and dissolution of his ministry. In carrying out its duties as stipulated in Article 8 of Law Number 39 the Year 2008 concerning State Ministries, the State Ministry carries out the functions of the formulation, stipulation, and implementation of policies in its fields, management of state property/assets that are its responsibility, supervision of the implementation of tasks in their areas and implementation technical activities of the center to the regions (Muin, 2015).

Moreover, to provide useful information to interested parties, the information presented in financial reporting must meet qualitative characteristics so that it can be used in decision making (Obaidat, 2007; Shahwan, 2008). Nevertheless, regarding to Callao et al., (2007), and Nugraha et al., (2020), stated the criteria that must be owned by financial reporting to meet the needs of users, including relevant, reliable, comparable, understandable, timely, and cost/benefit. It was stressed that relevant and reliable financial reporting could help in producing useful information. Still, if the financial statements cannot be compared, it cannot be understood and are not timely, and the costs are higher than the benefits it will reduce its usefulness. The preparation of financial reports in the government sector is a form of transparency requires that is a supporting requirement for accountability in the way of government transparency to public resource management activities (Putra, 2018). Financial statements are prepared to provide relevant information about the financial position and all transactions carried out by a reporting entity during one reporting period cycle (Gordon et al., 2004). Furthermore, according to (Bushman \& Piotroski, 2006), states that one of the factors that influence the quality of financial reporting in the private sector is the corporate supervision mechanism. The same thing was conveyed by Bauwhede et al., (2003) about potential factors that could affect financial reporting, namely the quality of the company's external governance mechanisms (such as audit quality), and the company's internal governance mechanism (such as the quality of the board of directors).

Also, management decisions and regulations related to financial reporting, such as internal and external corporate governance mechanisms, will affect the quality of financial reporting (Utami, 2015). Where the better the implementation of good corporate governance, the tendency of the quality of financial statements has good quality too. One of the fairest assessments of the information presented in local government financial statements is based on compliance with existing government accounting standards (J. L. Chan, 2003). According to Oulasvirta (2014), the theories that underlie government accounting standards are normative frameworks different from the development of accounting theories in private sector accounting standards that are positbive frameworks.

According to the state financial audit standard (SPKN) issued by the BPK of the Republic of Indonesia in 2007, it states that the fairness principle assessment of financial statements is based on generally accepted accounting principles (GAAP) (BPK, 2007). This GAAP must be a conceptual framework consisting of accounting standards, various laws and regulations, and sound accounting practices. However, there have never been explicit provisions regarding GAAP. In addition, SPKN does not explain the characteristics of GAAP as a basis for evaluating fairness in the context of governance, which, of course, will be very different from the GAAP understood so far. As a result, the assessment of the fairness of the BPK in LKKL is no more than a formality and has not yet made an optimal contribution to decisions made based on information contained in LKKL (Budiawan \& Purnomo, 2014). A financial statement audit is an audit conducted by an independent auditor on the financial statements presented by his client to express an opinion about the reasonableness of the financial reports (Suryo et al., 2019). In this financial statement audit, an independent auditor assesses the reasonableness of the financial statements based on their compliance with generally accepted accounting principles. Regarding Damanik \& Shauki (2018) and Nugraha et al., (2020), convey opinions that can be given by auditors on the results of audits of financial statements are divided into four types, namely: (i) unqualified opinion; (ii) qualified opinion, (iii) adversed opinion, (iv) disclaimer of opinion.

The definition of inspection according to the Law of the Republic of Indonesia Number 15 of 2006 concerning the Supreme Audit Board (BPK) is the process of identifying problems, analyzing, and evaluating independently, objectively, and professionally based on inspection standards to assess the truth, accuracy, credibility, and reliability of financial information regarding the management and responsibilities of state finances. By the law, the state institution whose task is to examine the management and duties of state finances, as referred to in the 1945 Constitution of the Republic of Indonesia, is the BPK. Furthermore, according to the mandate of Law No. 15 of 2004 concerning audits of management and responsibility of state finances includes three types, namely financial audits, performance audits, and audits with specific objectives. The fairness representation is then expressed in the form of opinion by considering the suitability criteria of financial statements with Government Accounting Standards (SAP), the adequacy of disclosure, compliance with laws and regulations, and the effectiveness of internal control (Badjuri, 2012; Putra, 2018). Following Article 23 of the 1945 Constitution, which states that the Supreme Audit Board (BPK) is an Indonesian state institution that has the authority to examine the management and responsibilities of state finances. The Supreme Audit Board 
(BPK) is an external auditor who is an independent auditing agency. Regarding to Goodwin (2004) and Lapsley (1999), state that the institutions that manage and carry out public sector audits differ from the private sector; this is due to the influence of specific laws. Differences due to institutional and legal backgrounds make public sector audits have broader procedures, responsibilities, and roles than the private sector. In the United States, this is known as "expanded scope audit," while in Canada, it is called "comprehensive auditing." The existence can see public sector audits that are broader than audit legislation for the private sector of compliance audits, financial audits, efficiency, and effectiveness that have explicit provisions in addition to attestation of financial statements (Goodwin, 2004). The examination is the process of identifying problems, analysis, and evaluations carried out independently, objectively, and professionally, based on examination standards to assess the truth, accuracy, credibility, and reliability of information regarding the management and responsibility of state finances.

Materiality is the amount of value that is omitted or misstated accounting information, seen from the circumstances that surround it, which may cause a change in influence on the consideration of people who place trust in the news due to the omission or misstatement. There are three levels of materiality that are used to determine the type of opinion to be published, namely the value is not material; the cost is substantial. Still, it does not affect the overall presentation of the financial statements. The value is very tangible so that the reasonableness of all financial statements is questioned. Determination of the level of materiality is one of the most important decisions taken by the auditor, which requires adequate professional judgment (Andrianto, 2015). In the technical guidelines and guidelines for LKKL examination, it is explained that the findings will affect opinion if it relates to both factors, namely the element of limitation of scope (restraints by the auditee, incomplete, inadequate documents, and uncertainty) which means the examiner cannot apply the audit standard (deviation audit standards) and financial statement factors are not presented by generally accepted accounting principles and are not consistently used (deviations from accounting principles). The following matters can cause the occurrence of audit standard deviation and the deviation from the accounting principle:

- If the examiner is obstructed or unable to obtain sufficient evidence to evaluate whether the impact has or will have a material effect on the financial statements, the examiner can give a fair opinion with an exception or not provide an opinion on the financial statements, depending on the potential impact on the overall financial statements;

- If internal control is weak and results in incomplete accounting records and/or inadequate documents available and/or the system does not produce valid accounting data, the examiner can't carry out adequate inspection procedures to cause the examiner to provide WDP opinion due to scope restrictions. If the system built is not in line with accounting principles, and the entity does not correct the impact of the misstatement, the examiner cannot provide a WTP opinion due to a violation of accounting principles.

\section{Method}

The object of this study is the report on the results of the examination of the financial statements of the state ministries in 2012-2017 (BPK, 2013, 2014, 2015, 2016, 2017). This research is a descriptive exploratory study. Explorative studies are carried out if not much is known about the situation at hand, or no information is available about how similar research problems or issues have been resolved in the past (Sekaran \& Bougie, 2016). This is very consistent with this research because there is still limited research that discusses the relationship between opinion of the BPK audit results and the quality of state institutions.

In this study, there are no population and sample issues, because sampling is the process of selecting a sufficient number of elements from the community so that research on the example and understanding of its nature or characteristics will enable us to generalize these traits or features to the population element past (Sekaran \& Bougie, 2016). While this research does not aim to conclude because this research is an exploratory study which aims to present the factors that form the basis of BPK in determining opinion on the results of audits of LKKL, knowing the quality of the implementation of state institutions (ministries) based on BPK Audit Opinion Results, Internal Control Systems and LKKL adherence to the Laws Regulations, fostering financial statements of departments in setting various rules that aim to improve the quality of financial reports and to find out follow-up recommendations from BPK RI.

The selection of participants is based on reports on the results of examinations on the financial statements of the state ministries that can be collected, as many as 216 (two hundred and sixteen) reports on the results of audits of state ministries from 2012 to 2017 audited by the BPK (BPK, 2013, 2014, 2015, 2016, 2017).

Analysis of exceptions in the audit report of the regional government financial statements that obtain a fair opinion with the exception is carried out using content analysis. Content analysis is a systematic technique in categorizing words into content/content categories using specific coding rules (Mayring, 2004). According to (K. W. Chan \& Elliott, 
2004), in general, there are two types of content analysis, namely conceptual analysis and relational analysis. However, traditional conceptual analysis is the kind of content analysis that is most often used. Theoretical analysis can be used to determine the existence and frequency of concepts that are displayed in the words that most often appear in a text, so it can be determined how many times the word appears. The steps in the conceptual analysis which are then implemented in this study, determine the level of analysis, determine how many types of concepts are used as code, determine whether the system is carried out for the existence or frequency of ideas, discover how to distinguish between concepts, explain the rules in coding, decide what will be done with irrelevant information, encode texts, analyze the results.

\section{Results and Discussion}

In this study, 216 (two hundred and sixteen) reports on the results of the state ministry's financial audits from 2012 to 2017 were audited by the Supreme Audit Board (BPK RI), with details of 30 LKKL who obtained WTP-DPP opinion, 36 LKKL got WDP opinion and 9 LKKL who received TMP opinion because there are accounts in the financial statements that are presented not by SAP. LKKL which obtained TMP opinion, because there are accounts in the financial statements that are presented not by SAP, include:

- Current assets, that is, there is a difference between transfers of supplies in and out of inter-work units that cannot be explained at the Ministry of Defense. Inventories in the form of ships resulting from procurement are recorded not by the physical realization of the work, and there is no detailed breakdown of the unit price of the components at the Ministry of Maritime Affairs and Fisheries (KKP);

- Fixed assets, i.e., traced or unclear whereabouts. The recording of fixed assets in the form of land, roads, networks, and irrigation, and Construction in Work (KDP) on the KKP is inaccurate, including negative value assets, KDP is not supported by physical progress documents and adequate cost budget plans, presentation of depreciation value exceeds the value acquisition, transaction mutation cannot be traced, and there are differences in recording the amount and size of fixed assets between the data on State Property (BMN) Management and Accounting Information Systems (SIMAK), cooperation agreements and MoF approval. The Ministry of Youth and Sports does not have an SOP on fixed assets. It has not yet made a specific code/inventory number of goods, BMN reports produced by SIMAK BMN are not following the actual conditions, and equipment and machinery fixed assets cannot be traced for Rp14.52 billion;

- Complete and valid documents do not support other assets, i.e. the presentation of patent value and the results of the study, the balance of other assets is negative because the amortization value exceeds the acquisition value and the unexplained value difference between the balance sheet and SIMAK. This problem occurs at the Ministry of Maritime Affairs and Fisheries;

- Obligations, namely the procurement of fishing vessels not by technical specifications and unit price breakdown data is not available for each component of the ship resulting in debt recording errors. This problem occurs in the Ministry of Maritime Affairs, and Fisheries;

- Income, which is an inadequate income control system, among others employees, are allowed to find partners and have extensive authority and responsibility, the concurrent function of business development functions with the reception depositor, the receipt is not deposited to the state treasury and used directly without adequate recording. The problem occurs in the Ministry of Defense;

- Spending, namely the realization of the expenditure is not supported by complete evidence and doubtful validity, using the maximum budget ceiling, not indicated real, can not be traced evidence of accountability and payment for capital expenditure procurement only based on estimates of physical progress work without regard to components that are not installed. This problem occurs at the Ministry of Maritime Affairs and Fisheries.

The results of BPK's examination of LKKL in 2012-2017 revealed the presence of internal control standards (SPI) weaknesses. The weaknesses of the SPI consist of weaknesses in the accounting and reporting control systems, weaknesses in the control system for the implementation of the revenue and expenditure budget, and weaknesses in the internal control structure. Problems with SPI's weaknesses in LKKL examinations include:

- Weaknesses in the accounting and reporting control system, namely that records have not been made or are inaccurate at the Ministry of Public Works and Public Housing (PUPR), including land and building fixed assets recorded at much lower values than reasonable price and recorded with a negative or zero balance, current service income, deposit interest and tariff income for the Housing Financing Liquidity Facility (FLPP) at the Public Service Agency (BLU) Center for Housing Financing Fund Management (PPDPP) has not been 
recorded as BLU revenue;

- The report preparation process is not following the provisions; namely, the report preparation process is not by the provisions of the Ministry of Education and Culture, including the presentation of returns on teacher professional allowance expenditure, incentive allowances and special allowances for teachers not Civil Servants (PNS) to The CaLK is not accurate, reports on the distribution of Indone Program funds Smart Clearance (PIP) from channeling banks is inaccurate because there are differences in PIP recipient data between channeling banks and the Ministry of Education and Culture, and channeling banks have not flagged the disbursement status as a sign that students have disbursed PIP funds, transferring computer data files from inventory applications to the Agency Accounting System Accrual Based (SAIBA) results in inaccurate inventory value details. The report preparation process was not by the provisions of the Ministry of Home Affairs, including classifying heavily damaged assets not based on physical inventory, not yet carrying out reconciliation and handover of assets with regional stakes in the context of liquidation of 507 Deconcentration and Assistance Task Force;

- Accounting information system and Inadequate reporting, namely the accounting information system and inadequate reporting to the Ministry of Finance, including controlling the input of data of the Tax Deposit (SSP) on the billing system of the Directorate General of Taxation (DJP) does not guarantee the accuracy of the classification of tax revenue accounts and the efforts to correct such inaccuracies cannot be accommodated in the accounting system for preparing financial statements, there is no policy related to the mechanism for write off tax receivables and export duty receivables in the framework of exports and imports determined by the Directorate General of Customs and Excise (DJBC) and the elimination of expired tax receivables that are presented in extractable terms. Deviations from regulations on revenue and expenditure at the Ministry of Environment and Forestry (KLHK), including the application system used for the management of PNBP Natural Resources (SDA), namely the Forest Product Administration Information System (SIPUHH), PNBP Information System (SI-PNBP) and the PNBP Online Information System (SIMPONI) is not yet integrated, and it is still possible to have to pay reports on production manually and calculate the obligations without going through the SIPUHH application. Accounting and reporting information systems are inadequate at the Ministry of Foreign Affairs, including the application of the Financial Management Information System (SIMKEU) that does not produce an accurate exchange rate to be able to present cash balance statements in rupiah and has not reconciled between balances at SIMKEU, SAIBA, and physical cash;

- Weaknesses in the Controlling System for the Implementation of the Revenue and Expenditure Budget, namely the deviation of regulations on revenue and expenditure at the Ministry of Education and Culture, including assistance to the film development center distributed in cash, there are recipients of government assistance receiving more than one aid, as well as control over Request Letters Payment (SPP), Payment Order (SPM), and Disbursement Warrant (SPPn) related to government aid spending is inadequate, the mechanism for receiving Corporate Social Responsibility (CSR) funds is not by the provisions of the grant and is used directly. Irregularities in regulations regarding income and expenditure at the Ministry of Social Affairs, including the use of a personal account as a temporary shelter account for the payment of performance allowances and salary deductions. Additional Money Supply (TUP) at the Center for Social Rehabilitation for Health Development (BBRSBD) Prof. DR. Soeharso Surakarta in 2017 worth Rp430.31 million was used to finance expenditures before the TUP was realized. The deviation of regulations on revenue and expenditure at the Ministry of Youth and Sports, among others, the Indonesian Asian Para Games Organizing Committee (INAPGOC) aid in 2017 is stored in a safe and used to finance activities in January-April 2018 because the 2018 budget cannot be disbursed;

- Inadequate Activity Planning, that is, inadequate planning of activities at the Ministry of Agriculture, among others there was an error in budgeting for spending at 14 work units, distribution of agricultural machinery equipment assistance was not yet fully supported by the stipulation of SK Candidates for Farmers / Prospective Land and proposed needs of farmer groups. Inadequate planning of activities at the Ministry of Defense, including the implementation of multi-year contracts that have not yet been approved by the Minister of Finance and the payment of the cost of medical examinations for the current year only to be paid the following year. Inadequate planning of activities at the Ministry of Health, including no budget allocation for integrated development postal packages so that the postal parcels have not been distributed valued at Rp.6.61 billion and Rp3.94 billion worth of expiry, procurement of patient monitoring equipment and anesthesia machines at the Hospital General of the Cipto Mangunkusumo National Center (RSUPNCM) and the printing of latrines for the patronization program were carried out without a needs analysis; 
- The implementation of policies resulted in increased spending, i.e., the implementation of policies resulted in increased spending at the Ministry of Agriculture, including the activities of the Investigation and Design Survey (SID) in the Province North Sulawesi in the context of printing new paddy is wasting state finance worth Rp3.00 billion because the SID location reserves in 2016 are still available, new paddy-printed land has the potential to be not utilized, among others because the land is lined with protected forests, and the water network infrastructure is not yet sufficient. ai. The implementation of the policy resulted in an increase in spending at the Ministry of Health, including provisions related to the amount of public service agency (BLU) remuneration value not by the maximum limit of remuneration set in the Decree of the Minister of Finance;

- Problems with the weaknesses of the control system for the implementation of the revenue and expenditure budget, namely the implementation of policies resulting in the loss of potential revenue and the mechanism for managing state revenues, not by the provisions;

- Weaknesses in the Internal Control Structure, i.e., SOPs have not been compiled/incomplete at the Ministry of Finance, between Other SOPs are related to examinations to test the fairness of the price of export surrender to affiliates and the imposition of administrative sanctions, credit of input taxes related to integrated palm oil company plantations, and fiscal corrections on the formation of premium reserves for the life insurance sector. SOPs have not been compiled/incomplete at the Ministry of Energy and Mineral Resources, including SOPs related to the management of natural resource revenues, revenue from the public service agency (BLU) of Oil and Gas Institutions (Lemigas), and the regulation of the government share of the results of cooperation in management services and data utilization in the oil and gas sector. other parties;

- SOPs have not been running optimally, that is, SOPs have not been running optimally at the Ministry of Communication and Information Technology, including among others, bad debts that have been protracted and have not been transferred to the Office of State Assets and Auction Services (KPKNL), non-performing institutions broadcasting has not been subject to the sanction of revocation and received an extension of the Broadcasting Permit (IPP), the sanction of revocation of IPP is carried out beyond the time limit stipulated in the provisions. The SOP has not been running optimally at the Ministry of Law and Human Rights, among others, changes in passport prices in the middle of the year by the Directorate General of Immigration Letter has not been used as a reference in determining the value of inventory in the distribution of passports abroad;

- Internal Supervisory Unit (SPI) is not optimal, namely The Internal Oversight Unit at the Ministry of Finance was not optimal, among others in following up the BPK audit recommendations related to controls in the determination of the Tax Collection Letter (STP) on the potential principal and tax administration sanctions.

In addition to the SPI issue, the results of the BPK examination also revealed the problem of non-compliance with statutory provisions. These problems covered the problem of non-compliance, which resulted in losses, potential losses, and lack of revenue (financial impact) worth Rp3.93 trillion and administrative irregularities (no financial impact). The problem of non-compliance, which has an economic impact, consists of problems that have caused losses of Rp.444.51 billion, potential losses of Rp.555.67 billion, and lack of revenue of Rp2.93 trillion. Regarding the problem of non-compliance, during the inspection process, $\mathrm{K} / \mathrm{L}$ has followed up by depositing money into the state treasury or handing over assets of Rp185.77 billion.

The examination results of LKKL revealed the problem of non-compliance with statutory provisions that resulted in losses of Rp.444.51 billion. These problems include lack of work and/or goods volume, overpayment in addition to lack of work/goods volume, spending not in accordance/exceeding provisions, double service costs, and/or not by provisions, goods/services specifications, not by the contract and other loss issues. The composition of the problem of non-compliance with statutory provisions that result in losses based on the value of the problem on the LKKL examination.

The problem of non-compliance resulted in a potential loss of Rp553.67 billion. These problems include assets controlled by other parties, overpaid work, but have not been paid off to partners and other potential loss problems. These problems generally occur because the responsible officials are not optimal in managing, controlling, and supervising accounts receivable and coordinating with the KPKNL to resolve bad debts, the responsible officials are negligent and inaccurate in obeying and understanding the applicable provisions and not yet optimal in carrying out management, administration, and security of BMN including dispute resolution and officials who have weak responsibilities in developing, supervising and controlling the implementation of goods/services procurement work and during contract maintenance.

The problem of non-compliance resulted in a lack of revenue of Rp2.93 trillion. These problems include late work penalties that have not been collected/received, acceptance other than late fees have not been collected/received, and 
other shortage of acceptance problems. These problems generally occur among others because related officials, Satker and PPK are less careful in supervising and controlling the implementation of work, collecting state revenues in their possession, taking action after the termination of the contract, unavailability of guidelines relating to the management of state revenue and problems with regulatory provisions in Ministry of Defense and the Military environment that is not by PMK Number 263/PMK.05/2015 concerning Procedures for Payment of Agreements in Foreign Currencies with Funds sourced from Pure Rupiah, service providers are not careful in carrying out work by the provisions in the contract.

Problems with administrative irregularities include irregularities in regulations in the management of equipment or BMN, and accountability is not accountable, the process of procurement of goods/services is not by the provisions, deviations in certain field regulations, and other administrative irregularities. Problems with administrative irregularities generally occur because the responsible official/executive is not optimal in conducting coaching, controlling and controlling, the official response is weak in conducting supervision and control, the responsible official does not fulfill the applicable provisions and does not verify the evidence of responsibility, the partner does not comply with the obligations stated in the contract.

BPK's recommendations to overcome the weaknesses of the SPI include preparing planning, recording, reconciliation, and monitoring carefully and periodically, carrying out duties and responsibilities by applicable SOPs, formulating, establishing and socializing the required SOP policies, following up on BPK's recommendations on the results of previous audits.

BPK's recommendations to overcome state losses due to non-compliance with statutory provisions include giving sanctions to officials/employees who have not been optimal in carrying out their duties and responsibilities by applicable regulations, carrying out their duties and responsibilities more carefully, increasing supervision and control and taking responsibility losses by depositing into the state treasury.

BPK's recommendations to overcome potential state losses due to non-compliance with statutory provisions include providing sanctions to related officials who are less than optimal in carrying out their duties and functions by their responsibilities, controlling and securing BMN, withdrawing fixed assets controlled by former employees/officials and other parties, improve the management, administration, supervision, and control of BMN, and coordinate with related parties by applicable regulations, among others, with the TPKN on lost assets and with law enforcement officials for assets controlled by other parties. Take into account overpayments by cutting term payments/repayments to partners, increasing coaching and controlling the implementation of work, and withdrawing payments that have been made to the provider or checking the work of the provider to calculate overpayments in subsequent payments or carry out repairs to damaged work in the period of maintenance to the relevant officials.

BPK's recommendations to overcome the problem of lack of revenue include giving sanctions by applicable regulations to related officials and increasing supervision and control over the implementation of work, collecting and depositing the lack of revenue to the state treasury by applicable regulations, compiling the necessary guidelines and complying with the provisions in force apply and improve coordination with related parties.

BPK's recommendations to overcome administrative irregularities include improving the fostering, controlling, and supervising the management of BMN, carrying out the grant/transfer status of BMN, and eliminating BMN by applicable laws, increasing supervision and control over the implementation of work by the provider, improve control and oversight of state revenue management, among others, by depositing state revenues following applicable regulations, tracing evidence of asset ownership, certifying land, and coordinating with relevant parties and completing evidence of accountability for the use of funds.

The follow-up on Examination Recommendation Results (TLRHP) monitoring is carried out systematically by the BPK to determine that the relevant officials have carried out the recommendations of the inspection results within the stipulated timeframe. According to BPK Regulation Number 2 of 2017 concerning Monitoring of the Implementation of Follow-Up Recommendations on the Results of BPK Examination, the results of the follow-up review are classified into four status groups, namely the follow-up is by the recommendations, the follow-up has not been by the recommendations, the recommendations have not been followed up, and the recommendations cannot be followed up.

The BPK has monitored 220,895 recommendations for the results of the 2012-2017 period valued at Rp 105.05 trillion to state ministry entities. As for the results of monitoring the follow up of the recommendations for the period as follows 157,613 recommendations $(71.3 \%)$ valued at Rp57.13 trillion by the recommendations, 47,414 recommendations $(21.5 \%)$ valued at Rp36.57 trillion were not by the recommendations, 14,956 recommendations (6, $8 \%$ ) worth IDR3.41 trillion has not been followed up, and 912 recommendations (0.4\%) worth IDR7.93 trillion cannot be followed up. 


\section{Conclusion}

The fairness assessment of the financial statements is seen from the conformity with government accounting standards, the adequacy of disclosure, compliance with laws and regulations, and the internal control system. From the results of the BPK RI audit for 2012-2017, there were 30 LKKL who obtained WTP-DPP opinion, 36 LKKL who received WDP opinion, and 9 LKKL who received TMP opinion, because there were accounts in the financial statements that were presented not by SAP. Accounts presented not by SAP on LKKL include current asset accounts, fixed asset accounts, liability accounts, income accounts, and shopping accounts. The problem of the discrepancy in account presentation with SAP has caused the exception of the BPK audit opinion. The results of BPK's examination of LKKL revealed the weaknesses of the Internal Control System (SPI), among others: gaps in the accounting and reporting control system, deficiencies in internal control structures, flaws in the implementation of the revenue and expenditure budget. The results of BPK's examination of LKKL revealed the problem of non-compliance with laws and regulations, which consisted of issues that resulted in losses of IDR447.51 billion, potential losses of IDR553.67 billion, and lack of revenue valued at IDR2.93 trillion. Regarding the problem of non-compliance, during the inspection process, the K/L has followed up by depositing money into the state treasury or handing over assets of Rp. 185.33 million.

The problems contained in the excluded accounts in the audit report of the participant's financial statements related to the fairness criteria of the financial statements include non-compliance with government accounting standards and weaknesses in the internal control system. While the inadequacy of disclosure is not a problem in accounts that are excluded from the participant's financial statements, and for non-compliance with statutory regulations are explained in the appendix. Problems with administrative irregularities include irregularities in the field of equipment management or BMN by $32 \%$; accountability is not accountable by $28 \%$, the process of procurement of goods/services is not by the provisions of $14 \%$, deviations in specific field regulations by $8 \%$, and other administrative deviations by $12 \%$. The results of the follow up on the recommendation from the Supreme Audit Board (BPK RI) have not been adequately followed up, and no mechanism can guarantee that the findings of the audit and other reviews have been resolved appropriately. Still, the implementation of the existing follow-up is attached with the evidence settlement and settlement by recommendations. The BPK has monitored 220,895 recommendations for the results of the 2012-2017 period valued at $\mathrm{Rp} 105.05$ trillion to state ministry entities. The results of the follow-up monitoring of advice for the period include: by the recommendations of 157,613 recommendations ( $71.3 \%$ ) valued at Rp57.13 trillion, not by the recommendations of 47,414 recommendations (21.5\%) worth Rp36.57 trillion, and the proposals have not followed up by 14,956 recommendations (6.8\%) worth IDR3.41 trillion and recommendations could not be followed up for 912 recommendations $(0.4 \%)$ worth IDR7.93 trillion.

The BPK's examination results on the financial statements revealed that in general, the quality of LKKL's presentation had improved during 2012-2017. The improvement in class can be seen from the increasing number of entities that obtain Unqualified Opinion (WTP) and the decreasing tendency of the number of objects that collect Unqualified Opinion (WDP) and Not Providing Opinion (TMP) opinions. The examination results of LKKL showed an increase in the percentage of WTP opinion and a decrease in the interest of WDP opinion and TMP. These conditions generally describe the improvements achieved by local government entities in presenting an excellent financial report by applicable principles. Furthermore, the presentation of an appropriate financial statement is an illustration and result of better business management.

\section{References}

Andrianto, N. (2015). The Development of Performance Audit Capacity, A Comparison Study in The BPK and ANAO. Jurnal Tata Kelola \& Akuntabilitas Keuangan Negara, 1(1), 21-42.

Badjuri, A. (2012). Analysis Faktor-Faktor yang Mempengaruhi Kualitas Hasil Pemeriksaan Audit Sektor Publik (Studi Empiris pada BPKL Perwakilan Jawa Tengah). Dinamika Akuntansi, Keuangan Dan Perbankan, 1(2), 120-135.

Ballesta, J. P. S., \& García-Meca, E. (2005). Audit qualifications and corporate governance in Spanish listed firms. Managerial Auditing Journal, 20(7), 725-738. https://doi.org/10.1108/02686900510611258

Bauwhede, H. V., Willekens, M., \& Gaeremynck, A. (2003). Audit firm size, public ownership, and firms' discretionary accruals management. The International Journal of Accounting, 38(1), 1-22. https://doi.org/10.1016/S0020-7063(03)00004-9

Biondi, Y. (2012). Should Business and Non-Business Accounting be Different? A Comparative Perspective Applied to the French Central Government Accounting Standards. International Journal of Public Administration, 35(9), 603-619. https://doi.org/10.1080/01900692.2012.661186
BPK.
(2013).
Ikhtisar
Hasil
Pemeriksaan Tahun
2013.
Retrieved
April
1, 2020,
from 
https://www.bpk.go.id/ihps/2013/II

BPK. (2014). Ikhtisar Hasil Pemeriksaan Tahun 2014. Retrieved April 1, 2020, from https://www.bpk.go.id/ihps/2014/II

BPK. (2015). Ikhtisar Hasil Pemeriksaan Tahun 2015. Retrieved April 1, 2020, from https://www.bpk.go.id/ihps/2015/II

BPK. (2016). Ikhtisar Hasil Pemeriksaan Tahun 2016. Retrieved April 1, 2020, from https://www.bpk.go.id/ihps/2016/II

BPK. (2017). Ikhtisar Hasil Pemeriksaan Tahun 2017. Retrieved April 1, 2020, from https://www.bpk.go.id/ihps/2017/II

BPK, B. P. K. (2007). Peraturan BPK No 1 Thn 2007: Standar Pemeriksaan Keuangan Negara (SPKN). Retrieved March 31, 2020, from https://ngada.org/bpk1-2007.htm

Budiawan, D. A., \& Purnomo, B. S. (2014). Pengaruh Sistem Pengendalian Internal Dan Kekuatan Koersif Terhadap Kualitas Laporan Keuangan Pemerintah Daerah. Jurnal Riset Akuntansi Dan Keuangan, 2(1), 276-288. https://doi.org/10.17509/jrak.v2i1.6581

Bushman, R. M., \& Piotroski, J. D. (2006). Financial reporting incentives for conservative accounting: The influence of legal and political institutions. Journal of Accounting and Economics, 42(1-2), 107-148. https://doi.org/10.1016/j.jacceco.2005.10.005

Callao, S., Jarne, J. I., \& Laínez, J. A. (2007). Adoption of IFRS in Spain: Effect on the comparability and relevance of financial reporting. Journal of International Accounting, Auditing and Taxation, 16(2), 148-178. https://doi.org/10.1016/j.intaccaudtax.2007.06.002

Chan, J. L. (2003). Government accounting: An assessment of theory, purposes and standards. Public Money and Management, 23(1), 13-20. https://doi.org/10.1111/1467-9302.00336

Chan, K. W., \& Elliott, R. G. (2004). Relational analysis of personal epistemology and conceptions about teaching and learning. Teaching and Teacher Education, 20(8), 817-831. https://doi.org/10.1016/j.tate.2004.09.002

Cohen, J., Krishnamoorthy, G., \& Wright, A. (2004). The Corporate Governance Mosaic and Financial Reporting Quality. Journal of Accounting Literature, 23, 87-152. https://doi.org/Doi 10.1016/S0266-3538(98)00151-1

Damanik, S., \& Shauki, E. R. (2018). Analisis Opini Laporan Hasil Pemeriksaan BPK RI (Studi pada Badan Keamana Laut RI). Jurnal Perbendaharaan, Keuangan Negara Dan Kebijakan Publik, 3(4), 330-346.

Effendy, Y. (2013). Tinjauan Hubungan Opini WTP BPK dengan Kasus Korupsi pada Pemda di Indonesia Kajian Manajemen Keuangan Pemerintah, Hubungan antara Masyarakat, Pemerintah dan Pemeriksa (Auditor). Jurnal Manajemen Dan Bisnis, 13(1), 46-55. Retrieved from http://jurnal.umsu.ac.id/index.php/mbisnis/article/view/107/54

Goodwin, J. (2004). A comparison of internal audit in the private and public sectors. Managerial Auditing Journal, 19(5), 640-650. https://doi.org/10.1108/02686900410537766

Gordon, E. A., Henry, E., \& Palia, D. (2004). Related Party Transactions and Corporate Governance. Advances in Financial Economics, 9, 1-27. https://doi.org/10.1016/S1569-3732(04)09001-2

Grilli, V., Masciandaro, D., Tabellini, G., Malinvaud, E., \& Pagano, M. (1991). Political and Monetary Institutions and Public Financial Policies in the Industrial Countries. Economic Policy, 6(13), 341. https://doi.org/10.2307/1344630

Hendri, F. (2017). "Opini WTP dari BPK Tidak Menjamin Bebas Korupsi. Retrieved March 30, 2020, from https://tirto.id/opini-wtp-dari-bpk-tidak-menjamin-bebas-korupsi-cpHe

Lapsley, I. (1999). Accounting and the New Public Management: Instruments of Substantive Efficiency or a Rationalising Modernity?. Financial Accountability \& Management, 15(3-4), 201-207. https://doi.org/10.1111/1468-0408.00081

Mayring, P. (2004). A Companion to Qualitative Research (1st ed.). Retrieved from https://books.google.co.id/books?hl=en\&lr=\&id=61wPkSo2XW8C\&oi=fnd\&pg=PP282\&dq=Content+analysis +is+a+systematic+technique+\&ots=Zq-X3rStKg\&sig=9cARUUwh5BlHpachG0Q8RBBfGe8\&redir_esc=y\#v= onepage \&q=Content analysis is a systematic technique $\& \mathrm{f}=$ false

Muin, F. (2015). Perlindungan Hukum Terhadap Tenaga Kerja Indonesia (Tinjauan Terhadap UU Nomor 39 Tahun 
2004 Tentang Penempatan dan Perlindungan Tenaga Kerja Indonesia). Jurnal Cita Hukum, 11-24(1), 1689-1699. https://doi.org/10.1017/CBO9781107415324.004

Nugraha, E., Nugroho, L., \& Setiawan, A. (2020). Discourses of Determinants Factor in Audit Quality. In The 1st Annual Conference Economics, Business, and Social Sciences. https://doi.org/10.4108/eai.26-3-2019.2290776

Nugroho, L., \& Kiranti, D. E. (2017). Pengaruh Motivasi dan Kompetensi Aparatur Terhadap Kualitas Informasi Akuntansi Barang Milik Negara. Jurnal Sistem Informasi, Keuangan, Auditing \& Perpajakan, 2(1), 20-34. https://doi.org/10.32897/jsikap.v2i1.61

Nugroho, L., Nurrohmah, S., \& Anasta, L. (2018). Faktor-Faktor Yang Mempengaruhi Opini Audit Going Concern. Jurnal SIKAP (Sistem Informasi, Keuangan, Auditing Dan Perpajakan), 2(2), 96. https://doi.org/10.32897/jsikap.v2i2.79

Obaidat, A. N. (2007). Auditors Compliance with International Standards on Auditing (ISAs): Evidence form Jordan. Journal of Social Sciences, 3(4), 185-189.

Oulasvirta, L. (2014). The reluctance of a developed country to choose International Public Sector Accounting Standards of the IFAC. A critical case study. Critical Perspectives on Accounting, 25(3), 272-285. https://doi.org/10.1016/j.cpa.2012.12.001

Purba, H., Sarpingah, S., \& Nugroho, L. (2020). The Effect of Implementing E-Filing Systems on Personal Tax Compliance with Internet Knowledge as Moderated Variables (Case Study on Personal Taxpayers at KPP Pratama Jakarta Kramatjati). International Journal of Commerce and Finance, 6(1), 166-180.

Putra, Y. M. (2018). Analisa Opini Hasil Audit BPK pada Laporan Keuangan Lembaga Negara terhadap Kualitas Penyelenggaraan Lembaga Negara Menggunakan Content Analysis (Studi Kementerian Negara di Indonesia Tahun 2012-2016). Ekonomi Dan Bisnis, 5(2), 116. https://doi.org/10.35590/jeb.v5i2.930

Sekaran, U., \& Bougie, R. (2016). Research Methods For Business: A Skill Building Approach. John Wiley \& Sons. Retrieved

from https://books.google.co.id/books?hl=en\&lr=\&id=Ko6bCgAAQBAJ\&oi=fnd\&pg=PA19\&dq=Research+method s+for+business:+A+skill+building+approach\&ots=2B5QZ5I_mP\&sig=bfjSuyh19EupVWN6CXBsCoJLb-4\&re dir_esc $=\mathrm{y} \# \mathrm{v}=$ onepage $\& \mathrm{q}=$ Research methods for business\%3A A skill building

Shahwan, Y. (2008). Qualitative characteristics of financial reporting: a historical perspective. Journal of Applied Accounting Research, 9(3), 192-202. https://doi.org/10.1108/JHOM-09-2016-0165

Sondakh, J., \& Mentu, E. P. (2016). Penyajian Laporan Keuangan Daerah Sesuai Peraturan Pemerintah No.71 Tahun 2010 Tentang Standar Akuntansi Pemerintahan Pada Dinas Pendapatan Daerah Dan Dinas Sosial Prov. Sulut. Jurnal Riset Ekonomi, Manajemen, Bisnis Dan Akuntansi, 4(1), 1392-1399.

Suryo, M., Nugraha, E., \& Nugroho, L. (2019). Pentingnya Opini Audit Going Concern dan Determinasinya. Inovbiz: Jurnal Inovasi Bisnis, 7(2), 123-130.

Utami, W. (2015). Financial Performance and the Quality of Sustainability Disclosure Based on Global Reporting Initiative: Value Relevances Study in Indonesia Stock Exchange. Mediterranean Journal of Social Sciences, 6(5), 243-248. https://doi.org/10.5901/mjss.2015.v6n5s5p243

Wahab, E. A. A., Zain, M. M., \& Rahman, R. A. (2013). Political connections: a threat to auditor independence? Journal of Accounting in Emerging Economies, 5(2), 222-246.

Widyanita. (2017). Tren Korupsi Meningkat, KPK Dikebiri - Infografik Katadata.co.id. Retrieved March 31, 2020, from https://katadata.co.id/infografik/2017/09/07/tren-korupsi-meningkat-kpk-dikebiri

Wungow, J. F., Lambey, L., \& Pontoh, W. (2016). Pengaruh Tingkat Pendidikan, Masa Kerja, Pelatihan Dan Jabatan Terhadap Kualitas Laporan Keuangan Pemerintah Kabupaten Minahasa Selatan. Jurnal Riset Akuntansi Dan Auditing “Goodwill," 7(2), 174-188. https://doi.org/10.35800/jjs.v7i2.13560

\section{Copyrights}

Copyright for this article is retained by the author(s), with first publication rights granted to the journal.

This is an open-access article distributed under the terms and conditions of the Creative Commons Attribution license (http://creativecommons.org/licenses/by/4.0/). 